\title{
Effect of Nitrogen Limitation on Growth, Biochemical Composition and Cell Ultrastructure of the Microalga Picocystis Salinarum
}

Ronald Tarazona Delgado ( $\nabla$ ronald.mtd@hotmail.com )

Department of Biological Sciences https://orcid.org/0000-0003-1366-6269

Mayara dos Santos Guarieiro

Department of Biological Sciences

Paulo Wagnner Antunes

Department of Environmental Engineering

Sérvio Túlio Cassini

Department of Environmental Engineering

Haydee Montoya Terreros

Natural History Museum

Valéria de Oliveira Fernandes

Department of Biological Sciences

Research

Keywords: biodiesel, biomass, lipids, lipid droplet, microalgae

Posted Date: November 12th, 2020

DOI: https://doi.org/10.21203/rs.3.rs-103539/v1

License: (9) (i) This work is licensed under a Creative Commons Attribution 4.0 International License.

Read Full License 


\section{Abstract}

In recent years, biodiesel production has attracted worldwide attention due to the awareness of fossil fuel depletion, and microalgae biomass is considered a promising raw material for its formulation. The present study evaluated the effects of different levels of nitrogen limitation $\left(37.5,18.75,9.375 \mathrm{mg} \mathrm{L}^{-1}\right.$ $\mathrm{NaNO}_{3}$ ) on the growth, cell ultrastructure and biochemical composition of Picocystis salinarum as a potential raw material source for biodiesel. During a culture period of 20 days, the growth measurements were estimated, and cell density, dry weight and chlorophylls $a, b$ content decreased with time as nitrogen limitation increase, however, carotenoids content increased. The high N limitation $\left(9.375 \mathrm{mg} \mathrm{L}^{-1}\right)$ had a highly significant effect on the accumulation of total lipid content (33.87\% dry weight), carbohydrate content increase ( $30.98 \%$ dry weight), but protein content decrease ( $1.89 \%$ dry weight). The lipid content showed a differential FAME profile with high saturated fatty acid values (996.08 $\mu^{g^{-1}}$ dry weight) mainly $\mathrm{C} 16: 0$, compare with the unsaturated ones that showed low values under high $\mathrm{N}$ limitation. The gradual increase of lipid content was also corroborated by transmission electron microscopy images with lipid droplet cell formation. Therefore, evaluation of the algal culture conditions such as $\mathrm{N}$ limitation, as a strategy to maximize lipid content and improve the fatty acid profile in unexplored halophilic $P$. salinarum showed a potential biomass yield as a suitable candidate for biodiesel production.

\section{Introduction}

The common use of petroleum-based fuels is widely recognized as unsustainable, it has been considered a global concern due to the exhaustion of its stocks, and the huge emission of greenhouse gases into the atmosphere contribute to climate change (Tan et al. 2018). Between, substitute alternatives to petroleum products (diesel fossils) the biodiesel has become a potential renewable fuel and its use leads to a reduction of harmful carbon dioxide emissions and the elimination of sulfur oxide emissions (Francisco et al 2010).

Biodiesel could be derived from food crops as edible oilseeds (sunflower, palm, soy, coconut), considered first-generation raw materials. However, mass production of alternative fuel source as terrestrial oil crops may cause shortage for food supply as well as deforestation (Chen et al. 2018; Rawat et al. 2013; Tandon and Jin 2017). Recently, non-food crops (non-edible seeds: pine nut, karanja, jojoba, mahua), edible oils residues, and animal fats, have gained importance as second-generation raw materials. Nevertheless, they do not have enough lipid content to replace biofuel current needs (Rawat et al. 2013; Tandon and Jin 2017).

In this context, microalgae emerged as biodiesel source to cover global demand for fuel due to their high growth rate, photosynthetic efficiency, and high lipid content biosynthesis (Chen et al. 2018; Chisti 2007). Consequently, microalgae biomass yield is considered as the third generation raw material for biodiesel. Their use does not interfere with food production and competition for arable land is reduced, and the water volume requirement is much lower for their biomass production compare to cultivable plants in the agronomic activity. Besides, certain microalgae biomass contains other biomolecules including 
carbohydrates, proteins and pigments that can be used for different secondary value-added products such as food, pharmaceutical or cosmetic additives (Demirbas and Demirbas 2011; Tandon and Jin 2017).

Microalgae can be grown in several synthetic media based on freshwater or seawater. To avoid competition for freshwater and significantly contribute to the biodiesel economy from microalgal biomass, the selection of a cultivable strain in seawater is mandatory (San Pedro et al. 2013). Although many oleaginous microalgae have already been studied, there are a large number of unexplored species, mainly from extremophile continental aquatic ecosystems (acidophilic, alkaliphilic, halophilic or thermophilic), which may have an even greater potential as a source of grease raw material for biodiesel production (Malavasi et al. 2020; Sanchez Rizza et al. 2017). Furthermore, it is necessary to manipulate the biochemical composition of the strain to increase their lipid content with synthesis of specific fatty acids for biodiesel formulation by adjusting the nutrient composition, salinity or $\mathrm{pH}$ of the media, and varying culture conditions such as light, temperature or photoperiod (Juneja et al. 2013).

Nutrient depletion is an approach to target metabolic pathways in lipid synthesis as the main reserve substance in microalgae. Although it has been reported that phosphorus and iron channel the metabolic flux to lipid biosynthesis under normal conditions, nitrogen is considered the most effective nutritional limiting factor for triggering high oil contents (Courchesne et al. 2009). Between the green microalgae, the halophilic Picocystis salinarum had registered intracellular lipid droplets during its cultivation under nitrogen limitation (Wang et al. 2014).

Therefore, the present research aimed to evaluate the effect of nitrogen limitation as a strategy to increase the lipid and fatty acid productivity of the biomass of $P$. salinarum as a potential raw material for biodiesel. In addition, analysis of changes in biochemical composition, growth and cell ultrastructure of this microalga is reported.

\section{Methods}

\section{Strain and culture conditions}

The Picocystis salinarum strain USM 303650 was obtained from the Herbarium of the Natural History Museum, National University of San Marcos, and its culture was carried out at the Laboratory of Taxonomy and Ecology of Algae Continents, Federal University of Espírito Santo.

The microalga was cultured in $\mathrm{f} / 2$ medium (Guillard 1975), prepared with filtered seawater ( $35 \mathrm{ppm}$ $\mathrm{NaCl}), \mathrm{pH}$ was adjusted to 8 , and autoclaving sterilization was done $\left(121^{\circ} \mathrm{C}, 20 \mathrm{~min}\right)$. The cultures were maintained under constant aeration, and controlled conditions of temperature $\left(29 \pm 1^{\circ} \mathrm{C}\right)$, light intensity $\left(47.25 \mu \mathrm{mol} \mathrm{m}^{2} \mathrm{~s}^{-1}\right)$ using $40 \mathrm{~W}$ daylight fluorescent lamps, and photoperiod (12:12 h, light:dark cycle). Batch cultures were grown in $3 \mathrm{~L}$ Erlenmeyer flasks $(2.7 \mathrm{~L}$ culture medium and $0.3 \mathrm{~L}$ of axenic inoculum with $9.5 \pm 0.5 \times 10^{5}$ cells $\mathrm{mL}^{-1}$ ) for twenty-days. Lyophilization was set up to obtain microalgal biomass. 


\section{Experimental design}

Cultivation experiments were conducted to evaluate and compare the algal growth, cell ultrastructure and biochemical composition of the $P$. salinarum strain under different nitrogen limitation conditions. The original sodium nitrate concentration ( $\left.75 \mathrm{mg} \mathrm{L}^{-1}\right)$ in $\mathrm{f} / 2$ medium is reported as $1 \mathrm{~N}$ (normal conditions). This was modified to serial dilutions: $1 / 2,1 / 4$ and $1 / 8$ times, receiving the nominations $0.5 \mathrm{~N}, 0.25 \mathrm{~N}$ and $0.125 \mathrm{~N}$ respectively.

\section{Growth assessment}

Cell density $\left(10^{6}\right.$ cell $\left.\mathrm{mL}^{-1}\right)$ was determined by direct counting in a Neubauer hemocytometer under an optical microscope (Olympus, CX41, Japan), every two days during the culture period (20 days). Dry weight $\left(\mathrm{g} \mathrm{L}^{-1}\right)$ was calculated by gravimetry every four days, culture aliquots $(20 \mathrm{~mL})$ were filtered in a glass fiber microfilter (Macherey Nagel, GF-1 $47 \mathrm{~mm}$, Germany), followed by over drying at $60{ }^{\circ} \mathrm{C}$ until constant weight.

\section{Quantification of photosynthetic pigments}

Chlorophylls $a$, and $b$, as well as total carotenoids were extracted in $90 \%$ acetone and measured every four days in a spectrophotometer (Thermo Scientific, AquaMate Plus, USA). Pigments concentration ( $\mu \mathrm{g}$

$\mathrm{L}^{-1}$ ) were calculated according to the equations proposed by Jeffrey and Humphrey (1975) and Strickland and Parsons (1968), respectively.

\section{Determination of protein, carbohydrate and total lipid}

Total protein content was determined according to Lowry et al. (1951). For alkaline hydrolysis, $4 \mathrm{~mL}$ of 1 $\mathrm{N} \mathrm{NaOH}$ was added to $5 \mathrm{mg}$ of microalgal biomass, and the mixture was incubated at $100{ }^{\circ} \mathrm{C}$ for $1 \mathrm{~h}$ and centrifuged at $3000 \mathrm{rpm}$ for $30 \mathrm{~min}$. Then, $5 \mathrm{~mL}$ of solution of $2 \% \mathrm{Na}_{2} \mathrm{CO}_{3}$ in $0.1 \mathrm{~N} \mathrm{NaOH}, 0.5 \%$ CuSO4 and $1 \% \mathrm{KNaC}_{4} \mathrm{H}_{4} \mathrm{O}_{6}(100: 1: 1, \mathrm{v} / \mathrm{v} / \mathrm{v})$ was added to $0.5 \mathrm{~mL}$ aliquot of the alkaline extract. The mixture was kept for $10 \mathrm{~min}$ at room temperature. Then, $0.5 \mathrm{~mL}$ of Folin-Ciocalteau reagent in distilled water (1: 1, $\mathrm{v} / \mathrm{v}$ ) was added and the mixture was incubated for $30 \mathrm{~min}$. The blue complex was analyzed in a spectrophotometer set at $750 \mathrm{~nm}$ against a calibration curve of albumin solution of known concentration as the standard.

Total carbohydrate content of the microalgal biomass was determined using the phenol-sulfuric acid method proposed by Kochert (1978). For this purpose, $5 \mathrm{mg}$ of biomass was tested to alkaline hydrolysis. Afterward, $1 \mathrm{~mL}$ of $1 \mathrm{~N} \mathrm{NaOH}$ and $0.05 \mathrm{~mL}$ of $4 \%$ phenol were added to $0.5 \mathrm{~mL}$ aliquot of alkaline extract. The mixture was kept in an oven at $25^{\circ} \mathrm{C}$ for $30 \mathrm{~min}$. Then, $2.5 \mathrm{~mL}$ of sulfuric acid was added to the mixture and was kept for $5 \mathrm{~min}$ at room temperature. The yellow-brown complex was analyzed by spectrophotometric analysis at $485 \mathrm{~nm}$ against a calibration curve (anhydrous glucose solution). 
Total lipid was extracted according to Bligh and Dyer (1959). $7.5 \mathrm{~mL}$ chloroform and methanol solution $(1: 2, \mathrm{v} / \mathrm{v})$ was added to $0.5 \mathrm{~g}$ biomass. The mixture was vortexed for $2 \mathrm{~min}$ followed by addition of 2.5 $\mathrm{mL}$ chloroform and $2.5 \mathrm{~mL}$ distilled water, and vortexed again. Subsequently, the mixture was centrifuged at $3500 \mathrm{rpm}$ at $4{ }^{\circ} \mathrm{C}$ for $8 \mathrm{~min}$. The organic phase with the extracted lipids was separated and placed in an oven at $30^{\circ} \mathrm{C}$ for organic solvent evaporation. Finally, the total lipids were calculated gravimetrically.

The total protein, carbohydrate and lipid concentrations are given as $\mathrm{mg} \mathrm{g}^{-1}$ and biomass dry weight (\% DW).

\section{Transmission electron microscopy (TEM)}

Cell ultrastructure was studied using the TEM which was performed according to the method of Souza et al. (2017) with minor modifications. Samples (0.05 mg microalgal biomass) were washed in phosphatebuffered saline and fixed with $2.5 \%$ glutaraldehyde in $0.1 \mathrm{M}$ cacodylate buffer at $4{ }^{\circ} \mathrm{C}$ for $12 \mathrm{~h}$. Fixed samples were washed three times with cacodylate buffer for $10 \mathrm{~min}$. Post-fixation in $1 \% \mathrm{OsO}_{4}$ in $0.1 \mathrm{M}$ cacodylate buffer and $1.25 \% \mathrm{~K}_{4} \mathrm{Fe}(\mathrm{CN})_{6}(1: 1, \mathrm{v} / \mathrm{v})$ was followed by dehydration in an acetone series (30, $50,70,90$, and $100 \%)$. Later, they were infiltrated in epon resin and polymerized in an oven at $60^{\circ} \mathrm{C}$ for 48 $\mathrm{h}$. The resulting blocks were cut at $60 \mathrm{~nm}$ in an ultramicrotome (PowerTome, PT-XL, USA), and stained with $5 \%$ uranyl acetate and $1 \%$ lead citrate for 30 min each. The ultrathin sections were mounted on mesh $\mathrm{n}^{\circ} 400$ grids coated with formvar, and examined in the transmission electron microscope (JEOL, JEM1400 , Brazil), operated at $120 \mathrm{kV}$ with a LaB6 filament. Microphotographs were obtained for each nitrogen limitation treatments.

\section{Analysis of fatty acid methyl esters (FAMEs)}

Fatty acids were determined using high-performance liquid chromatography (HPLC) of methyl esters from microalgal biomass. First, the transesterification of biomass was performed according to Menezes et al. (2013) with few modifications. $2 \mathrm{~g}$ of biomass was suspended in $3 \mathrm{~mL}$ of $0.5 \mathrm{M} \mathrm{NaOH}$ in methanol, followed by heating at $70^{\circ} \mathrm{C}$ for $10 \mathrm{~min}$. Then, samples were cooled in an ice-water bath and added $9 \mathrm{~mL}$ of an esterifying solution of $\mathrm{NH}_{4} \mathrm{Cl}$ : methanol: $\mathrm{H}_{2} \mathrm{SO}_{4}(1: 30: 1.5, \mathrm{~g} / \mathrm{v} / \mathrm{v})$. Samples were again heated at 70 ${ }^{\circ} \mathrm{C}$, cooled in an ice-water bath, and $5 \mathrm{~mL}$ heptane and $2 \mathrm{~mL}$ distilled water were added to the mixture and vortexed. The heptane phase containing FAMEs were transferred into a tube and dried under a stream of nitrogen.

The FAMEs were dissolved in $10 \mu \mathrm{L}$ acetonitrile and analyzed in a chromatography system (Shimadzu, CBM-20A, Japan), equipped with a DGU-20AS solvent degasser, LC-20AT gradient quaternary pump, SIL20AHT automatic sample injector, SPD-M20A diode array detector and a $100 \mathrm{~mm} \times 2.1 \mathrm{~mm} \times 2.6 \mu \mathrm{m}$ Kinetex ${ }^{\circledR}$ C18 HPLC column (USA).

A binary mobile phase consisting of $(A)$ trifluoroacetic acid solution and distilled water $(0.1: 99.9, \mathrm{v} / \mathrm{v})$ and (B) acetonitrile were filtered using a vacuum filtration system through $0.45 \mu \mathrm{m}$ membrane filters and degassed in an ultrasound bath (Limpsonic, Brazil). The HPLC system was programmed to operate under 
controlled conditions of column temperature $\left(37^{\circ} \mathrm{C}\right)$, detection wavelength $(210 \mathrm{~nm})$ and flow rate $(0.25$ $\left.\mathrm{mL} \mathrm{min}{ }^{-1}\right)$. The following gradient elution was employed: $0-1 \mathrm{~min}: 100 \% \mathrm{~A} ; 1-12 \mathrm{~min}: 90-70 \% \mathrm{~A}, 20$ - 40\% B; 12 - 32 min: $100-90 \%$ A, $62-40 \%$ B; 32 - 32.5 min (column equilibration): 100\% A. The fatty acids were analyzed by comparing their retention time of the corresponding peaks with a known standard mixture of FAMEs added to each sample as the standard. LCSolutions 2.1 software was used for data acquisition and analysis.

\section{Statistical analysis}

The tests were performed using triplicates for each treatment. Means and standard deviation (SD) were calculated for all treatments, and significant differences were determined by analysis of variance according to Tukey's highly significant differences test $(p<0.05)$. Comparison among the treatments was performed by one-way ANOVA test $(p<0.05)$. Principal component analysis (PCA) was used to determine the relationship between all tests analyzed. ANOVA and Tukey's test were performed using the SPSS 20.0 software, and the PCA using the XLSTAT 2020 software.

\section{Results And Discussion}

\section{Growth measurements}

The growth of microalgae depends on an adequate supply of nutrients mainly nitrogen, phosphorus and micronutrients. Nitrogen $(\mathrm{N})$ is a major component in many biological macromolecules like chlorophylls, proteins and DNA. Under $\mathrm{N}$ depletion, microalgae grow in a medium lacking of $\mathrm{N}$ source, while under $\mathrm{N}$ limitation there is a constant but insufficient $\mathrm{N}$ availability. Therefore, the $\mathrm{N}$ nutrient stress on cellular physiology negatively affects microalgal growth such as cell density and dry biomass (Benavente-Valdés et al. 2016; Ördög et al. 2012).

The $P$. salinarum growth response was proportional to the $\mathrm{N}$ concentration in the medium during the culture period ( 20 days). The control culture $(1 \mathrm{~N})$ reached the highest values of cell density from the $18^{\text {th }}$ day until the end of culture period on the $20^{\text {th }}$ day $\left(13.1 \times 10^{6}\right.$ cells $\left.\mathrm{mL}^{-1}\right)$, and a gradual decrease in the population growth with the increase of nitrogen limitations $(0.5,0.25$ and $0.125 \mathrm{~N})$ (Fig. 1). These findings corroborate the results obtained by other researchers, who reported that microalgae cell density is directly proportional to the concentration of $\mathrm{N}$ in the culture medium (Chen et al 2011; Dean et al 2010; Illman et al 2000; Zhu et al. 2014).

Regarding the biomass yield through the dry weight (Fig. 2), the highest values were obtained in $1 \mathrm{~N}(0.96$ $\left.\mathrm{g} \mathrm{L}^{-1}\right)$ and $0.5 \mathrm{~N}\left(0.88 \mathrm{~g} \mathrm{~L}^{-1}\right)$ on the $20^{\text {th }}$ day. They were followed by the dry weight decrease in response to $\mathrm{N}$ limited availability under 0.25 and $0.125 \mathrm{~N}$ treatments. Similar studies in other green microalgae showed the dry mass decreased under $\mathrm{N}$ limitation, from $2.88 \mathrm{~g} \mathrm{~L}^{-1}$ to $0.97 \mathrm{~g} \mathrm{~L}^{-1}$ in Chlorella minutissima (Ördög et al. 2012) and from $1.17 \mathrm{~g} \mathrm{~L}^{-1}$ to $1.05 \mathrm{~g} \mathrm{~L}^{-1}$ in Dunaliella salina (Sathasivam et al. 2018). Under $\mathrm{N}$ 
depletion conditions, high dry weight decrease values from $1.39 \mathrm{~g} \mathrm{~L}^{-1}$ to $0.06 \mathrm{~g} \mathrm{~L}^{-1}$ was reported for Scenedesmus quadricauda (Anand and Arumugam 2015).

\section{Photosynthetic pigments}

$\mathrm{N}$ limitation decreased the chlorophyll content of P. salinarum (Fig. 3 a, b). Chlorophyll a content showed the highest values in the control since the $12^{\text {th }}$ day and reached $2.73 \mathrm{\mu g} \mathrm{mL}^{-1}$ on the $20^{\text {th }}$ day. However, a sharp dropped of $91.2 \%$ in chlorophyll a content was evidenced under the $0.125 \mathrm{~N}$ treatment by the end of the culture period. High chlorophyll $b$ content was obtained from the $16^{\text {th }}$ day to the $20^{\text {th }}$ day $\left(0.92 \mu \mathrm{gL}^{-}\right.$ $\left.{ }^{1}\right)$ in control culture. A high decrease of chlorophyll $b(84 \%)$ was notorious under nitrogen limitation $(0.125 \mathrm{~N}$ treatment). On the opposite, $P$. salinarum $\mathrm{N}$ limitation was related positively with the carotenoids content. The highest production started on the $12^{\text {th }}$ day with a gradual increase up to $3.35 \mu \mathrm{g} \mathrm{mL}^{-1}$ on the $20^{\text {th }}$ day in $0.125 \mathrm{~N}$ treatment, that is seven times higher than algal growth in the control culture (Fig. $3 \mathrm{c}$ ).

The photosynthetic pigments of the 0.5 and $0.25 \mathrm{~N}$ treatments showed intermediate values between 1 and $0.125 \mathrm{~N}$ treatments throughout the culture period. Then, the chlorophyll content was related positively to the nitrogen levels tested. However, the carotenoid accumulation was related negatively to the nitrogen levels. These results recognized in the culture flask coloration with greenish pigmentation at the beginning, later with time the cultures with normal nitrogen supply had an intense green color, however, those with the lowest nitrogen supply changed to a yellowish coloration.

Similar results were recorded in Dunaliella salina, with a chlorophyll content decreased from $27.90 \mu \mathrm{g} \mathrm{mL}^{-}$

1 to $10.20 \mu \mathrm{g} \mathrm{mL}^{-1}$, when the nitrogen concentration was reduced in half. Conversely, the carotenoid content increased from $99.43 \mu \mathrm{g} \mathrm{mL}^{-1}$ to $177.10 \mu \mathrm{g} \mathrm{mL}^{-1}$ (Sathasivam et al. 2018). Chlorophylls decreased and carotenoids increased in culture under $\mathrm{N}$ stress conditions were reported for the green freshwater microalgae Chlamydomonas reinhardtii (Cakmak et al. 2012) and Dunaliella tertiolecta (Young and Beardall 2003).

Therefore, there was a progressive loss of certain plastid functions, with impact in photosynthetic pigments such as the decrease in chlorophyll synthesis and an increase in carotenoids with the limiting nitrogen nutrient. This occurrence is related to the reorganization of the photosynthetic apparatus to maximize the efficiency of absorption of specific spectra of light under situations of nutritional stress (Young and Beardall 2003). Chlorophyll is a nitrogen-rich compound utilized as an intracellular nitrogen pool to support cell growth. Then, chlorophyll concentration would account for the cell density increase and biomass production registered in the control culture $\left(75 \mathrm{mg} \mathrm{L}^{-1}\right)$ and $0.5 \mathrm{~N}$ treatment $\left(37.5 \mathrm{mg} \mathrm{L}^{-1}\right)$.

\section{Biochemical composition}

Differential responses in total protein, carbohydrate, and lipid contents of $P$. salinarum under $\mathrm{N}$ limitation culture treatments are showed in Table 1. Nitrogen is an essential element for amino acid synthesis, its deficiency reduce dramatically protein biosynthesis, trigger the inhibition of citric acid cycle and a drastic 
cell division decrease due to protein reduction in the photosystem reaction center and photosynthetic electron transport (Deng et al. 2011; Msanne et al. 2012).

The total protein content of $P$. salinarum under 0.25 and $0.125 \mathrm{~N}$ treatments showed a remarkable decrease of $78.08 \mathrm{mg} \mathrm{g}^{-1}$ related to $7.81 \% \mathrm{DW}$ and $18.92 \mathrm{mg} \mathrm{g}^{-1}$ related to $1.8 \% \mathrm{DW}$, respectively (Table 1). Cobos et al. (2017) reported a decrease in protein content under $\mathrm{N}$ depletion for the freshwater microalgae species as follows: Acutodesmus obliquus from $12.8 \%$ to $9.7 \%$ DW, Ankistrodesmus sp. from $14.5 \%$ to $10.5 \%$ DW and Chlorella lewinii from $31.2 \%$ to $14.2 \%$ DW. Dean et al. (2010) reported an $18 \%$ decrease in the protein content of Chlamydomonas reinhardtii in response to $\mathrm{N}$ limitation. However, Cakmak et al. (2012) cited a notorious reduction up to $82 \%$ in this species.

Under $\mathrm{N}$ depletion or $\mathrm{N}$ limitation, alternative metabolic pathways for fixing inorganic carbon such as the synthesis of carbohydrates or lipids in microalgae are activated (Deng et al. 2011; Msanne et al. 2012; Pancha et al. 2014). The carbohydrates production is mainly related to the cell wall structural components and nutritional reserves (Markou et al. 2012). Our work demonstrated that carbohydrate content was the main biochemical fraction for cultures with high nitrogen concentrations: $1 \mathrm{~N}$ and $0.5 \mathrm{~N}$ with $43.14 \%$ and $43.56 \%$ DW, respectively. However, the low carbohydrate contents were obtained in $P$. salinarum grew under 0.25 and $0.125 \mathrm{~N}$ treatments with $34.48 \%$ and $30.98 \% \mathrm{DW}$, respectively. Therefore, under $\mathrm{N}$ extreme stress conditions that is $9.375 \mathrm{mg} \mathrm{L}^{-1} \mathrm{NaNO}_{3}(0.125 \mathrm{~N})$, carbohydrate content decreased and became the main second biomolecule followed by the lipid content (Table 1).

The effects of $\mathrm{N}$ limitation on the carbohydrates accumulation in cultures reported for Chlorella vulgaris represented 41\% DW (Dragone et al. 2011), 35\% DW in Tetraselmis subcordiformis (Yao et al. 2012) and 57\% DW in Desmodesmus sp. (Sanchez Rizza et al. 2017). However, Chlamydomonas reinhardtii increase up to its $80 \%$ DW (Cakmak et al. 2012; Siaut et al. 2011).

The lipids have a main role in cell membrane structural composition. Nevertheless, under nutritional limitation, due to their hydrophobic nature, lipids are derived as a storage product. They present very low states and are efficiently packaged in the cell and can be used under adverse conditions for survival and subsequent cell proliferation (Courchesne et al. 2009). The increase in total lipid content could be explained for a boost in transcript levels of genes encoding enzymes of the lipid biosynthesis pathways, specifically in the last step in the Kennedy pathway of triacylglycerol biosynthesis (Deng et al. 2011; Weiss et al. 1960).

In the present study, the $\mathrm{N}$ limitation caused an increase in the lipid content of $P$. salinarum, reaching the highest value of $33.87 \% \mathrm{DW}$ under $0.125 \mathrm{~N}$ treatment, becoming the main biomolecule. The lipid content increases in variable ways in other algae species, then in Nannochloropsisoceanica almost duplicate with increase from $7.9 \%$ to $15.31 \%$ DW, and in Chlorellavulgaris from $5.9 \%$ to $16.41 \%$ DW (Converti et al. 2009). Other species of Chlorella, C. emersonii and C. minutissima showed a high increase of lipids in the order of $63 \%$ and $56 \%$ DW, respectively (IIlman et al. 2000). However, in C. lewinii there was an increase 
from 9.5\% to $13.2 \%$ DW, in Acutodesmus obliquus from 15.2\% to $18.8 \%$ DW and in Ankistrodesmus sp. from $23.7 \%$ to $39.5 \%$ DW (Cobos et al. 2017).

\section{Cell ultrastructure}

The results previously described suggest that depending on the $\mathrm{N}$ concentration supplied and the type of species, the microalgae synthesize a certain biomolecule to face the nutritional deficit and continue with its development. In this context, the organic carbon generated by photosynthesis is related to the biomolecules production such as carbohydrates and lipids. They are storage in reserve subcellular structures and accumulated at expense of reduced growth rate (Msanne et al. 2012; Siaut et al. 2011).

In addition, the TEM analysis of $P$. salinarum vegetative cells under different $\mathrm{N}$ concentrations showed cell structural changes (Figure 4). Under normal conditions, longitudinal sections of cells showed oval shape with a typical chloroplast occupying most of the cell volume (Fig. 4 a). This observation was similar to TEM images recorded for same microalgae species (Glabonjat et al. 2020; Lopes Dos Santos et al. 2017). P. salinarum under nitrogen depletion treatments accumulated organic material reserve as starch grain and lipid droplet (LD) (oil body or oleosome) in several numbers and sizes for each treatment (Fig. 4 b, c, d).

It has been proposed that the lipids are synthesized and packaged initially in the plastid and then transported to the cytoplasm, where they form the LDs (Eltgroth et al. 2005). These structures are the main storage structure for neutral lipids in eukaryotic cells, and support evidence they are involve in other cellular processes such as lipid homeostasis and communication signaling between other organelles. The LD synthesis in response to specific cellular needs and their number per cell change according to the nutritional status conditions (Goold et al. 2015). Also under $\mathrm{N}$ limitation or $\mathrm{N}$ depletion conditions, both the number and size of the LDs can increase and the chloroplast became imperceptible, because they act as a sink for membrane-derived fatty acids, including plastid membrane lipids that are degraded (Goold et al. 2015; Roopnarain et al. 2014; Siaut et al. 2011).

The biochemical composition of $P$. salinarum was in agreement with our TEM results. In $0.5 \mathrm{~N}$ treatment, several starch grains dispersed were observed compared to LDs, and the chloroplast was hardly visible (Fig. 4 b). However, under $0.25 \mathrm{~N}$ treatment, the large LDs development was notorious as well as starch grains decreased (Fig. 4 c). Furthermore, at $0.125 \mathrm{~N}$ treatment, a dominant single LD occupied most of the cell volume as well as several small ones around it (Fig. 4 d).

Under normal growth conditions, Chlamydomonas reinhardtii has a single cup-shaped plastid that occupied more than two-thirds of the total cell volume, in some strains neither starch grains nor lipid droplets were detected. The appearance and accumulation of these reserve structures, as well as the reduction of plastid organelle, were notorious in cells under $\mathrm{N}$ depletion (Siaut et al. 2011). Zhu et al. (2014) observed in Chlorella zofingiensis an increase in starch grains both in size and number after the first days under $\mathrm{N}$ stress, with a few LDs. Through the coming days, the cells exhibited more LDs instead of starch granules. Then, small LDs fusion formed larger ones. Other studies reported that the starch 
granules can fuse and be converted into LDs, this analysis suggests that the carbon flux of starch must provide some of the precursors for lipid synthesis (Ito et al. 2013; Mizuno et al. 2013).

These findings were in agreement with our results and suggested the presence of a single large LD in $P$. salinarum cells under the high $\mathrm{N}$ limitation tested $(0.125 \mathrm{~N}$ treatment), as storage lipid product probably became greater as carbon source (starch grains) were useful during the algal growth period.

\section{Profile of fatty acid methyl esters (FAMEs)}

The determination of the FAMEs profile as well as the biomolecule concentrations related to their proportion with the dry weight are essential steps for characterizing microalgae strains as potential raw material source for biodiesel. The FAMEs analysis with the profile of saturated fatty acids (SFAs) and unsaturated fatty acids (UFAs) of $P$. salinarum under $\mathrm{N}$ limitation is presented in Table 2.

Among SFAs, the lauric acid (C12:0) content had a proportional reduced response to the supply decrease of $\mathrm{N}$ and not being detected at $0.125 \mathrm{~N}$ treatment. In contrast, palmitic acid (C16:0) and myristic acid (C14:0) increased their contents. Under the highest $\mathrm{N}$ limitation $(0.125 \mathrm{~N})$, the $\mathrm{C} 16: 0$ content reached a high value of $923.95 \mu \mathrm{g} \mathrm{g}^{-1}$ DW. Regarding to the UFAs, oleic acid (C18:1) also had a decrease content in response to the lowest $\mathrm{N}$ supply in cultures. In addition, linoleic acid (C18:2) and linolenic acid (C18:3) reported minimum values or were not detected in all treatments.

It is known that $\mathrm{N}$ limitation stimulates the $\mathrm{C} 16: 0$ production between the SFAs, as it were reported for green microalgae such as Chlorella vulgaris, Nannochloropsis oculata, Chlamydomonas reinhardtii, Dunaliella salina and Dunaliella tertiolecta (Chen et al. 2011; Converti et al. 2009; Lv 2016; Msanne et al. 2012). In our studies, the decrease in UFAs mainly $C 18: 2$ and $C 18: 3$ due to $N$ limitation was correlated with those registered for Coccomyxa sp. (Msanne et al. 2012). Besides, Anand and Arumugam (2015) reported that the main fatty acid detected (C18:1) in Scenedesmus quadricauda had a drastic reduction under $\mathrm{N}$ limitation. On the other hand, this fatty acid was not synthesized in some algae such as Dunaliella salina (Lv 2016). Therefore, it is confirmed that the microalgae cells tend to decrease the degree of fatty acid unsaturation in response to the $\mathrm{N}$ deficit.

The FAMEs profile plays an important role in the biodiesel quality. It determines its viscosity, lubricity, total unsaturation (iodine value), density, oxidative stability, cetane index (ignition quality indicator), cold flow property and calorific value (Francisco et al. 2010; Knothe 2005). The FAMEs of the microalgae are different from those of higher plants, the last are special rich in polyunsaturated fatty acids (PUFAs) such as C18:2 and C18:3. These have four or more double bonds, being more susceptible to oxidation during storage which reduce its acceptability for use in biodiesel use. Besides, as the PUFAs concentration is high, the biodiesel nitrate and nitrite emission rate increases (Chen et al. 2018; Chisti 2007; Francisco et al. 2010).

On the other hand, when the SFAs are high, they result in a lower cetane index and increase the biodiesel stability since the SFAs are more resistant to auto-oxidation (Knothe 2005). Guidelines international and 
regional control of oily biomass for biofuel use; like the requirements of the European Norms EN 14213 and EN 14214, pointed out that the C18:3 amount must have a limit lower than $12 \%$ of the total FAMEs for motor vehicles use (Knothe 2006). By this way, biomass highly rich in oils with high levels of saturated fatty acids is sought, and meets local criteria for use and biofuel production.

The PCA provided an overview of the $\mathrm{N}$ limitation effects on $P$. salinarum (Fig. 5). Its biochemical composition under control conditions $(1 \mathrm{~N})$ had the expected results in green microalgae, high growth (cell density and dry mass) was related to high contents of chlorophyll $a$ and $b$, proteins and carbohydrates. The same patterns were also followed with the $0.5 \mathrm{~N}$ treatment. Besides, the degree of fatty acids saturation was recognized under the 0.25 and $0.125 \mathrm{~N}$ treatments, mainly with the last treatment related to the lipid content, carotenoids and C16:0. P. salinarum biomass ( $0.125 \mathrm{~N}$ treatment) with high total lipid yield and adequate fatty acid composition that is high SFA content (C:16), and a low C18:3 (PUFA) met certain European Norms requirements. Therefore, it showed to be a competent and potential raw material source for the biodiesel production.

\section{Conclusions}

It is known, that the raw material composition for biodiesel, must be rich in lipids with certain group of fatty acids. The majority of higher plants and microalgae biomass have considerable contents of proteins and carbohydrates, but inadequate fatty acids composition, therefore, they would not be useful as a raw material for biofuel industry. To solve this performance problem, the approach developed in this work (decrease in the $\mathrm{N}$ supply in culture) reported the efficiency of lipid content with an adequate fatty acid profile in the halophilic extremophile $P$. salinarum. A reduction in the protein and carbohydrate content, but an increase of lipids under the high $\mathrm{N}$ limitation $(0.125 \mathrm{~N})$ was showed for $P$. salinarum biomass. The fatty acid profile obtained is an advantage due to the proportion between SFAs and UFAs for a suitable biodiesel. This also was supported with the TEM micrographs of cell cultures under stress $\mathrm{N}$ limitation with a single large-volume LD that suggested a large scale oil extraction would be performed successfully.

The findings of this research also suggest that $P$. salinarum biomass is a potential source of grease raw material suitable for the production of biodiesel, which could contribute to sustainable development as a viable alternative to petroleum exploration. However, it will be necessary to develop cultivation systems for biomass production on a large scale for biofuel production and additional bioactive compounds (carbohydrates and carotenoids) useful in other manufactures.

\section{Abbreviations}

ANOVA

Analysis of variance; DW:Dry weight; FAME:Fatty acid methyl ester; HPLC:High-performance liquid chromatography; LD:Lipid droplet; N:Nitrogen; PCA:Principal component analysis; PUFA:Polyunsaturated 
fatty acid; SD:Standard deviation; SFA:Saturated fatty acid; TEM:Transmission electron microscope; UFA:Unsaturated fatty acid.

\section{Declarations}

\section{Acknowledgements}

The authors thank Coordination for the Improvement of Higher Education Personnel - Brazil (CAPES) for financial support. Ronald Tarazona Delgado has been benefited by a scholarship from CAPES, and this work is part of his MSc thesis. The authors would also like to thank technicians of the Laboratory of Cellular Ultrastructure Carlos Alberto Redins, Federal University of Espírito Santo, for its support in transmission electron microscopy.

\section{Authors' contributions}

All authors made substantial contributions in conceptualizing, drafting, developing and reviewing the manuscript. The paper was reviewed and approved by all authors prior to submission for peer review.

\section{Funding}

This work was funded by the Coordination for the Improvement of Higher Education Personnel - Brazil (CAPES), Finance Code 001.

\section{Availability of data and materials}

The datasets used and/or analyzed during the current study are available from the corresponding author on reasonable request.

\section{Ethics approval and consent to participate}

Not applicable.

\section{Consent to publication}

Not applicable.

\section{Competing interests}

The authors declare that they have no competing interests.

\section{Author details}

${ }^{1}$ Department of Biological Sciences, Federal University of Espírito Santo, Vitória, ES 29075-015, Brazil. ${ }^{2}$ Natural History Museum, National University of San Marcos, Lima, LIM 14-0434, Peru. ${ }^{3}$ Department of Environmental Engineering, Federal University of Espírito Santo, Vitória, ES 29075-910, Brazil. 


\section{References}

1. Anand J, Arumugam M (2015) Enhanced lipid accumulation and biomass yield of Scenedesmus quadricauda under nitrogen starved condition. Bioresour Technol 188:190-194. https://doi.org/10.1016/j.biortech.2014.12.097

2. Benavente-Valdés JR, Aguilar C, Contreras-Esquivel JC, Méndez-Zavala A, Montañez J (2016) Strategies to enhance the production of photosynthetic pigments and lipids in chlorophycae species. Biotechnol Reports 10:117-125. https://doi.org/10.1016/j.btre.2016.04.001

3. Bligh EG, Dyer WJ (1959) A rapid method of total lipid extraction and purification. Can J Biochem Physiol 37:911-917. https://doi.org/10.1139/059-099

4. Cakmak T, Angun P, Demiray YE, Ozkan AD, Elibol Z, Tekinay T (2012) Differential effects of nitrogen and sulfur deprivation on growth and biodiesel feedstock production of Chlamydomonas reinhardtii. Biotechnol Bioeng 109:1947-1957. https://doi.org/10.1002/bit.24474

5. Chen J, Li J, Dong W, Zhang X, Tyagi RD, Drogui P, Surampalli RY (2018) The potential of microalgae in biodiesel production. Renew Sustain Energy Rev 90:336-346. https://doi.org/10.1016/j.rser.2018.03.073

6. Chen M, Tang H, Ma H, Holland TC, Ng KYS, Salley SO (2011) Effect of nutrients on growth and lipid accumulation in the green algae Dunaliella tertiolecta. Bioresour Technol 102:1649-1655. https://doi.org/10.1016/j.biortech.2010.09.062

7. Chisti Y (2007) Biodiesel from microalgae. Biotechnol Adv 25:294-306. https://doi.org/10.1016/j.biotechadv.2007.02.001

8. Cobos M, Paredes JD, Maddox JD, Vargas-Arana G, Flores L, Aguilar CP, Marapara JL, Castro JC (2017) Isolation and characterization of native microalgae from the Peruvian Amazon with potential for biodiesel production. Energies 10:1-16. https://doi.org/10.3390/en10020224

9. Converti A, Casazza AA, Ortiz EY, Perego P, Del Borghi M (2009) Effect of temperature and nitrogen concentration on the growth and lipid content of Nannochloropsis oculata and Chlorella vulgaris for biodiesel production. Chem Eng Process Process Intensif 48:1146-1151. https://doi.org/10.1016/j.cep.2009.03.006

10. Courchesne NMD, Parisien A, Wang B, Lan CQ (2009) Enhancement of lipid production using biochemical, genetic and transcription factor engineering approaches. J Biotechnol 141:31-41. https://doi.org/10.1016/j.jbiotec.2009.02.018

11. Dean AP, Sigee DC, Estrada B, Pittman JK (2010) Using FTIR spectroscopy for rapid determination of lipid accumulation in response to nitrogen limitation in freshwater microalgae. Bioresour Technol 101:4499-4507. https://doi.org/10.1016/j.biortech.2010.01.065

12. Demirbas A, Demirbas MF (2011) Importance of algae oil as a source of biodiesel. Energy Convers Manag 52:163-170. https://doi.org/10.1016/j.enconman.2010.06.055

13. Deng X, Fei X, Li Y (2011) The effects of nutritional restriction on neutral lipid accumulation in Chlamydomonas and Chlorella. African J Microbiol Res 5:260-270. 
https://doi.org/10.5897/AJMR10.557

14. Dragone G, Fernandes BD, Abreu AP, Vicente AA, Teixeira JA (2011) Nutrient limitation as a strategy for increasing starch accumulation in microalgae. Appl Energy 88:3331-3335.

https://doi.org/10.1016/j.apenergy.2011.03.012

15. Eltgroth M.L, Watwood RL, Wolfe GV (2005) Production and cellular localization of neutral long-chain lipids in the haptophyte algae Isochrysis galbana and Emiliania huxleyi. J Phycol 41:1000-1009. https://doi.org/10.1111/j.1529-8817.2005.00128.x

16. Francisco ÉC, Neves DB, Jacob-Lopes E, Franco TT (2010) Microalgae as feedstock for biodiesel production: Carbon dioxide sequestration, lipid production and biofuel quality. J Chem Technol Biotechnol 85:395-403. https://doi.org/10.1002/jctb.2338

17. Glabonjat RA, Blum JS, Miller LG, Webb SM, Stolz JF, Francesconi KA, Oremland RS (2020) Arsenolipids in cultured Picocystis strain ML and their occurrence in biota and sediment from Mono Lake, California. Life 10:1-21. https://doi.org/10.3390/life10060093

18. Goold H, Beisson F, Peltier G, Li-Beisson Y (2015) Microalgal lipid droplets: composition, diversity, biogenesis and functions. Plant Cell Rep 34:545-555. https://doi.org/10.1007/s00299-014-1711-7

19. Guillard RRL (1975) Culture of Phytoplankton for Feeding Marine Invertebrates. In: Smith WL, Chanley MH (eds) Culture of Marine Invertebrate Animals. Springer, Boston, MA. https://doi.org/10.1007/978-1-4615-8714-9_3

20. Illman AM, Scragg AH, Shales SW (2000) Increase in Chlorella strains calorific values when grown in low nitrogen medium. Enzyme Microb Technol 27:631-635. https://doi.org/10.1016/S01410229(00)00266-0

21. Ito T, Tanaka M, Shinkawa H, Nakada T, Ano Y, Kurano N, Soga T, Tomita M (2013) Metabolic and morphological changes of an oil accumulating trebouxiophycean alga in nitrogen-deficient conditions. Metabolomics 9:178-187. https://doi.org/10.1007/s11306-012-0463-z

22. Jeffrey SW, Humphrey GF (1975) New spectrophotometric equations for determining chlorophylls a, $b, c_{1}$ and $c_{2}$ in higher plants, algae and natural phytoplankton. Biochem und Physiol der Pflanz 167:191-194. https://doi.org/10.1016/s0015-3796(17)30778-3

23. Juneja A, Ceballos RM, Murthy GS (2013) Effects of environmental factors and nutrient availability on the biochemical composition of algae for biofuels production: A review. Energies 6:4607-4638. https://doi.org/10.3390/en6094607

24. Kochert G (1978) Carbohydrate determination by the phenol sulfuric acid method. In: Hellebust J, Craigie J (eds) Handbook of Phycological Methods. Physiological and Biochemical Methods. Cambridge, UK: Cambridge University Press.

25. Knothe $G$ (2005) Dependence of biodiesel fuel properties on the structure of fatty acid alkyl esters. Fuel Process Technol 86:1059-1070. https://doi.org/10.1016/j.fuproc.2004.11.002

26. Knothe G (2006) Analyzing biodiesel: Standards and other methods. J Am Oil Chem Soc 83:823833. https://doi.org/10.1007/s11746-006-5033-y 
27. Lopes Dos Santos A, Pollina T, Gourvil P, Corre E, Marie D, Garrido JL, Rodríguez F, Noël MH, Vaulot D, Eikrem W (2017) Chloropicophyceae, a new class of picophytoplanktonic prasinophytes. Sci Rep 7:1-20. https://doi.org/10.1038/s41598-017-12412-5

28. Lowry OH, Rosebrough NJ, Farr AL, Randall RJ (1951). Protein measurement with the Folin phenol reagent. J Biol Chem 193:265-275

29. Lv H, Cui X, Wang S, Jia S (2016) Metabolic profiling of Dunaliella salina shifting cultivation conditions to nitrogen deprivation. Metab Open Acess 6:2153. https://doi.org/10.4172/21530769.1000170 .

30. Malavasi V, Soru S, Cao G (2020) Extremophile Microalgae: the potential for biotechnological application. J Phycol 56:559-573. https://doi.org/10.1111/jpy.12965

31. Markou G, Angelidaki I, Georgakakis D (2012) Microalgal carbohydrates: An overview of the factors influencing carbohydrates production, and of main bioconversion technologies for production of biofuels. Appl Microbiol Biotechnol 96:631-645. https://doi.org/10.1007/s00253-012-4398-0

32. Menezes RS, Leles MIG, Soares AT, Brandão PI, Franco M, Filho NRA, Sant'anna CL, Vieira AAH (2013) Avaliação da potencialidade de microalgas dulcícolas como fonte de matéria-prima graxa para a produção de biodiesel. Quim Nova 36:10-15. https://doi.org/10.1590/S010040422013000100003

33. Mizuno Y, Sato A, Watanabe K, Hirata A, Takeshita T, Ota S, Sato N, Zachleder V, Tsuzuki M, Kawano $S$ (2013) Sequential accumulation of starch and lipid induced by sulfur deficiency in Chlorella and Parachlorella species. Bioresour Technol 129:150-155. https://doi.org/10.1016/j.biortech.2012.11.030

34. Msanne J, Xu D, Konda AR, Casas-Mollano JA, Awada T, Cahoon EB, Cerutti H (2012) Metabolic and gene expression changes triggered by nitrogen deprivation in the photoautotrophically grown microalgae Chlamydomonas reinhardtii and Coccomyxa sp. C-169. Phytochemistry 75:50-59. https://doi.org/10.1016/j.phytochem.2011.12.007

35. Ördög V, Stirk WA, Bálint P, van Staden J, Lovász C (2012) Changes in lipid, protein and pigment concentrations in nitrogen-stressed Chlorella minutissima cultures. J Appl Phycol 24:907-914. https://doi.org/10.1007/s10811-011-9711-2

36. Pancha I, Chokshi K, George B, Ghosh T, Paliwal C, Maurya R, Mishra S (2014) Nitrogen stress triggered biochemical and morphological changes in the microalgae Scenedesmus sp. CCNM 1077. Bioresour Technol 156:146-154. https://doi.org/10.1016/j.biortech.2014.01.025

37. Rawat I, Ranjith Kumar R, Mutanda T, Bux F (2013) Biodiesel from microalgae: A critical evaluation from laboratory to large scale production. Appl Energy 103:444-467. https://doi.org/10.1016/j.apenergy.2012.10.004

38. Roopnarain A, Gray VM, Sym S (2014) Influence of nitrogen stress on Isochrysis galbana strain U4, a candidate for biodiesel production. Phycol Res 62:237-249. https://doi.org/10.1111/pre.12054

39. San Pedro A, González-López CV, Acién FG, Molina-Grima E (2013) Marine microalgae selection and culture conditions optimization for biodiesel production. Bioresour Technol 134:353-361. 
https://doi.org/10.1016/j.biortech.2013.02.032

40. Sanchez Rizza L, Sanz Smachetti ME, Do Nascimento M, Salerno GL, Curatti L (2017) Bioprospecting for native microalgae as an alternative source of sugars for the production of bioethanol. Algal Res 22:140-147. https://doi.org/10.1016/j.algal.2016.12.021

41. Sathasivam R, Pongpadung P, Praiboon J, Chirapart A, Trakulnaleamsai S, Roytrakul S, Juntawong N (2018) Optimizing $\mathrm{NaCl}$ and $\mathrm{KNO}_{3}$ concentrations for high $\beta$-carotene production in photobioreactor by Dunaliella salina KU11 isolated from saline soil sample. Chiang Mai J. Sci. 45:106-115

42. Shuba ES, Kifle D (2018) Microalgae to biofuels: 'Promising' alternative and renewable energy, review. Renew Sustain Energy Rev 81:743-755. https://doi.org/10.1016/j.rser.2017.08.042

43. Siaut M, Cuiné S, Cagnon C, Fessler B, Nguyen M, Carrier P, Beyly A, Beisson F, Triantaphylidès C, LiBeisson Y, Peltier G (2011) Oil accumulation in the model green alga Chlamydomonas reinhardtii: Characterization, variability between common laboratory strains and relationship with starch reserves. BMC Biotechnol 11:7. https://doi.org/10.1186/1472-6750-11-7

44. Souza LS, Simioni C, Bouzon ZL, Schneider RCS, Gressler P, Miotto MC, Rossi MJ, Rörig LR (2017) Morphological and ultrastructural characterization of the acidophilic and lipid-producer strain Chlamydomonas acidophila LAFIC-004 (Chlorophyta) under different culture conditions. Protoplasma 254:1385-1398. https://doi.org/10.1007/s00709-016-1030-7

45. Strickland JDH, Parsons TR (1972) A Practical Handbook of Seawater Analyses; Fisheries Research Board of Canada: Ottawa, ON, Canada.

46. Tan XB, Lam MK, Uemura Y, Lim JW, Wong CY, Lee KT (2018) Cultivation of microalgae for biodiesel production: A review on upstream and downstream processing. Chinese $\mathrm{J}$ Chem Eng 26:17-30. https://doi.org/10.1016/j.cjche.2017.08.010

47. Tandon P, Jin Q (2017) Microalgae culture enhancement through key microbial approaches. Renew Sustain Energy Rev 80:1089-1099. https://doi.org/10.1016/j.rser.2017.05.260

48. Wang S, Lambert W, Giang S, Goericke R, Palenik B (2014) Microalgal assemblages in a poikilohaline pond. J Phycol 50:303-309. https://doi.org/10.1111/jpy.12158

49. Weiss SB, Kennedy EP, Kiyasu JY (1960) The enzymatic synthesis of triglycerides. J Biol Chem 235:40-44.

50. Yao C, Ai J, Cao X, Xue S, Zhang W (2012) Enhancing starch production of a marine green microalga Tetraselmis subcordiformis through nutrient limitation. Bioresour Technol 118:438-444. https://doi.org/10.1016/j.biortech.2012.05.030

51. Young EB, Beardall J (2003) Photosynthetic function in Dunaliella tertiolecta (Chlorophyta) during a nitrogen starvation and recovery cycle. J Phycol 39:897-905. https://doi.org/10.1046/j.15298817.2003.03042.x

52. Zhu S, Huang W, Xu J, Wang Z, Xu J, Yuan Z (2014) Metabolic changes of starch and lipid triggered by nitrogen starvation in the microalga Chlorella zofingiensis. Bioresour Technol 152:292-298. https://doi.org/10.1016/j.biortech.2013.10.092 


\section{Tables}

Table 1. Effect of nitrogen limitation on biochemical composition (total protein, carbohydrate and lipid content) of $P$. salinarum.

\begin{tabular}{|c|c|c|c|c|c|c|}
\hline \multirow[t]{2}{*}{ Treatment } & \multicolumn{2}{|l|}{ Total protein } & \multicolumn{2}{|c|}{ Total carbohydrate } & \multicolumn{2}{|l|}{ Total lipid } \\
\hline & $\left(\mathrm{mg} \mathrm{g}^{-1}\right)$ & (\% DW) & $\left(\mathrm{mg} \mathrm{g}^{-1}\right)$ & $(\% \mathrm{DW})$ & $\left(\mathrm{mg} \mathrm{g}^{-1}\right)$ & $(\% \mathrm{DW})$ \\
\hline $1 \mathrm{~N}$ & $134.75 \pm 9.92^{\mathrm{a}}$ & 13.48 & $431.42 \pm 11.34^{a}$ & 43.14 & $212.33 \pm 5.57^{c}$ & 21.23 \\
\hline $0.5 \mathrm{~N}$ & $139.75 \pm 5.42^{a}$ & 13.98 & $435.58 \pm 9.38^{a}$ & 43.56 & $218.67 \pm 4.04^{c}$ & 21.87 \\
\hline $0.25 \mathrm{~N}$ & $78.08 \pm 5.05^{b}$ & 7.81 & $344.75 \pm 7.5^{b}$ & 34.48 & $255.33 \pm 4.16^{b}$ & 25.53 \\
\hline $0.125 \mathrm{~N}$ & $18.92 \pm 4.73^{c}$ & 1.89 & $309.75 \pm 11.46^{c}$ & 30.98 & $338.67 \pm 7.21^{a}$ & 33.87 \\
\hline
\end{tabular}

Data are expressed as mean $\pm S D(n=3)$. Values with the different letters represent significant difference $(p<0.05)$ between treatments. DW: Dry weight.

Table 2. Composition of fatty acid methyl esters $\left(\mu \mathrm{g} \mathrm{g}^{-1} \mathrm{DW}\right)$ of $P$. salinarum under nitrogen limitation.

\begin{tabular}{|lrrrr|}
\hline Fatty acid & \multicolumn{4}{l}{ Treatment } \\
& \multicolumn{1}{l}{$1 \mathrm{~N}$} & $0.5 \mathrm{~N}$ & $0.25 \mathrm{~N}$ & $0.125 \mathrm{~N}$ \\
\hline C12:0 & $274.01^{\mathrm{a}}$ & $157.83^{\mathrm{b}}$ & $53.53^{\mathrm{c}}$ & - \\
\hline C14:0 & $59.15^{\mathrm{b}}$ & $28.99^{\mathrm{c}}$ & $79.65^{\mathrm{a}}$ & $72.13^{\mathrm{a}}$ \\
\hline C16:0 & $59.24^{\mathrm{d}}$ & $300.49^{\mathrm{c}}$ & $721.96^{\mathrm{b}}$ & $923.95^{\mathrm{a}}$ \\
\hline C18:1 & $111.32^{\mathrm{b}}$ & $96.38^{\mathrm{b}}$ & $254.24^{\mathrm{a}}$ & $0.61^{\mathrm{c}}$ \\
\hline C18:2 & $16.99^{\mathrm{a}}$ & - & $18.07^{\mathrm{a}}$ & $19.87^{\mathrm{a}}$ \\
\hline C18:3 & $0.92^{\mathrm{a}}$ & - & $1.64^{\mathrm{a}}$ & - \\
\hline SFA & $392.40^{\mathrm{c}}$ & $487.31^{\mathrm{b}}$ & $855.15^{\mathrm{a}}$ & $996.08^{\mathrm{a}}$ \\
\hline UFA & $129.23^{\mathrm{b}}$ & $96.38^{\mathrm{b}}$ & $273.95^{\mathrm{a}}$ & $20.48^{\mathrm{c}}$ \\
\hline
\end{tabular}

Data are expressed as mean $(n=3)$. Values with the different letters represent significant difference $(p<$ $0.05)$ between treatments. SFA: Saturated fatty acid, UFA: Unsaturated fatty acid, (-): not detected.

\section{Figures}




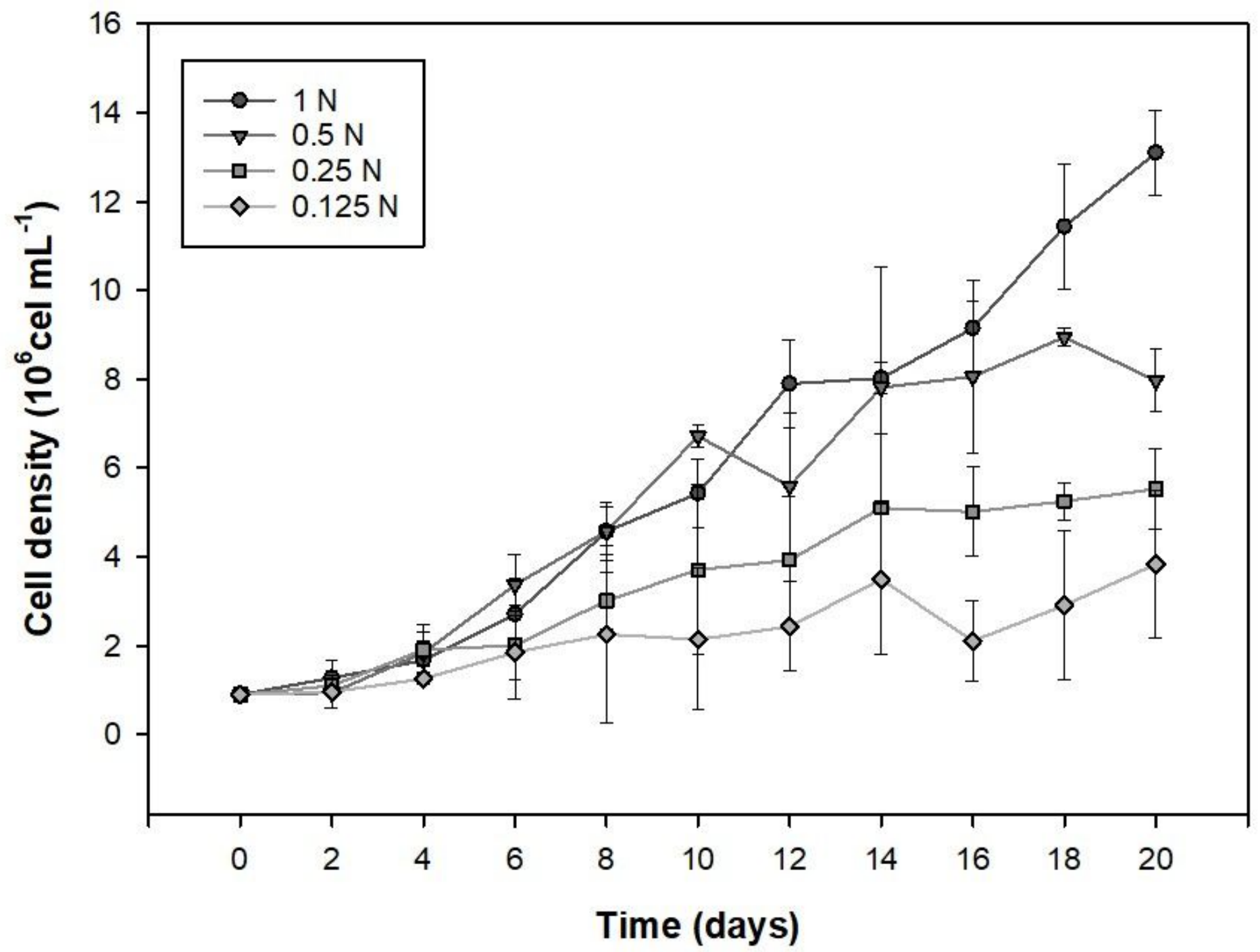

Figure 1

Effect of nitrogen limitation on the cell density of P. salinarum. Data are expressed as mean $\pm S D(n=3)$. Values with the different letters represent significant difference $(p<0.05)$ between treatments. 


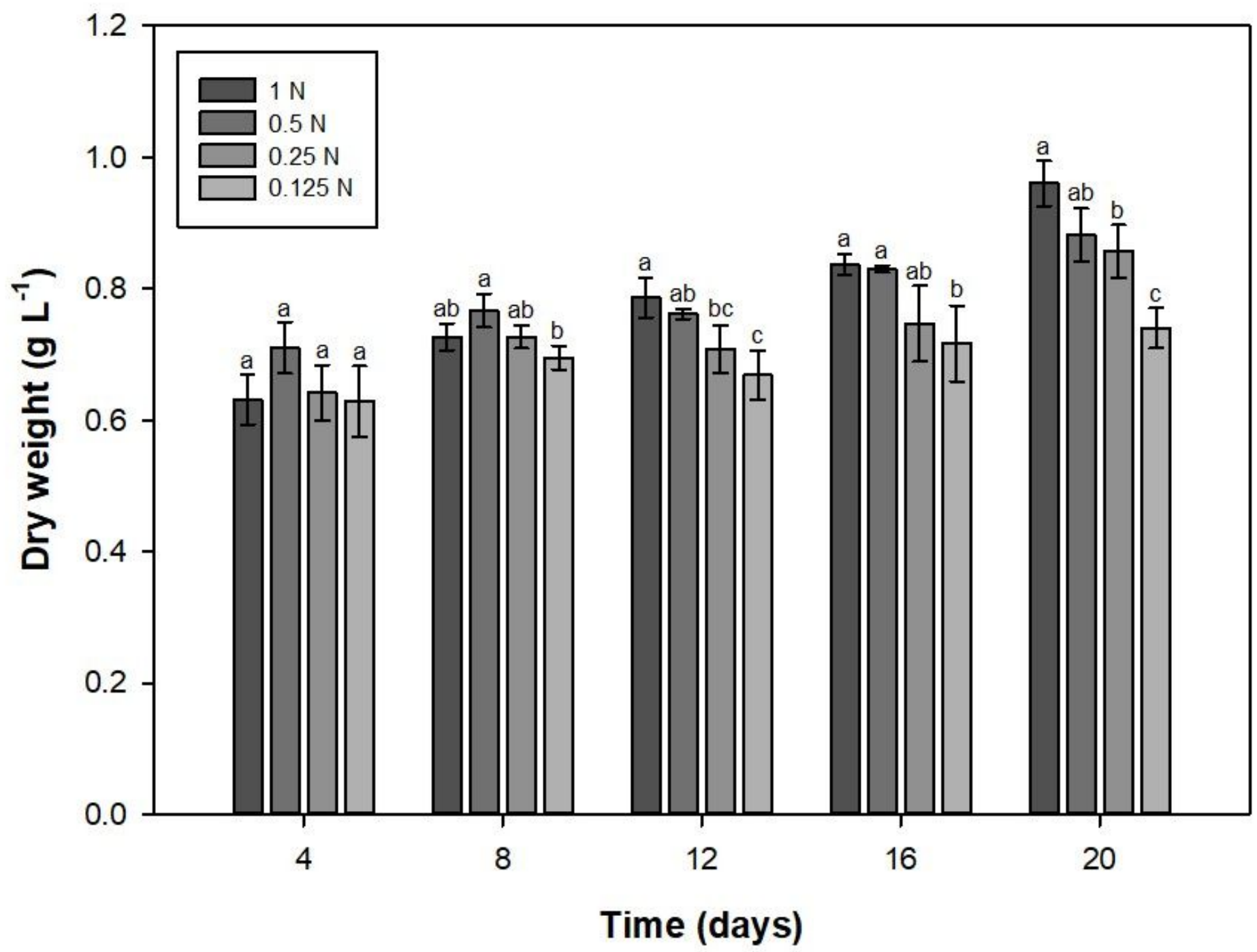

Figure 2

Effect of nitrogen limitation on the dry weight of P. salinarum. Data are expressed as mean $\pm S D(n=3)$. Values with the different letters represent significant difference $(p<0.05)$ between treatments. 

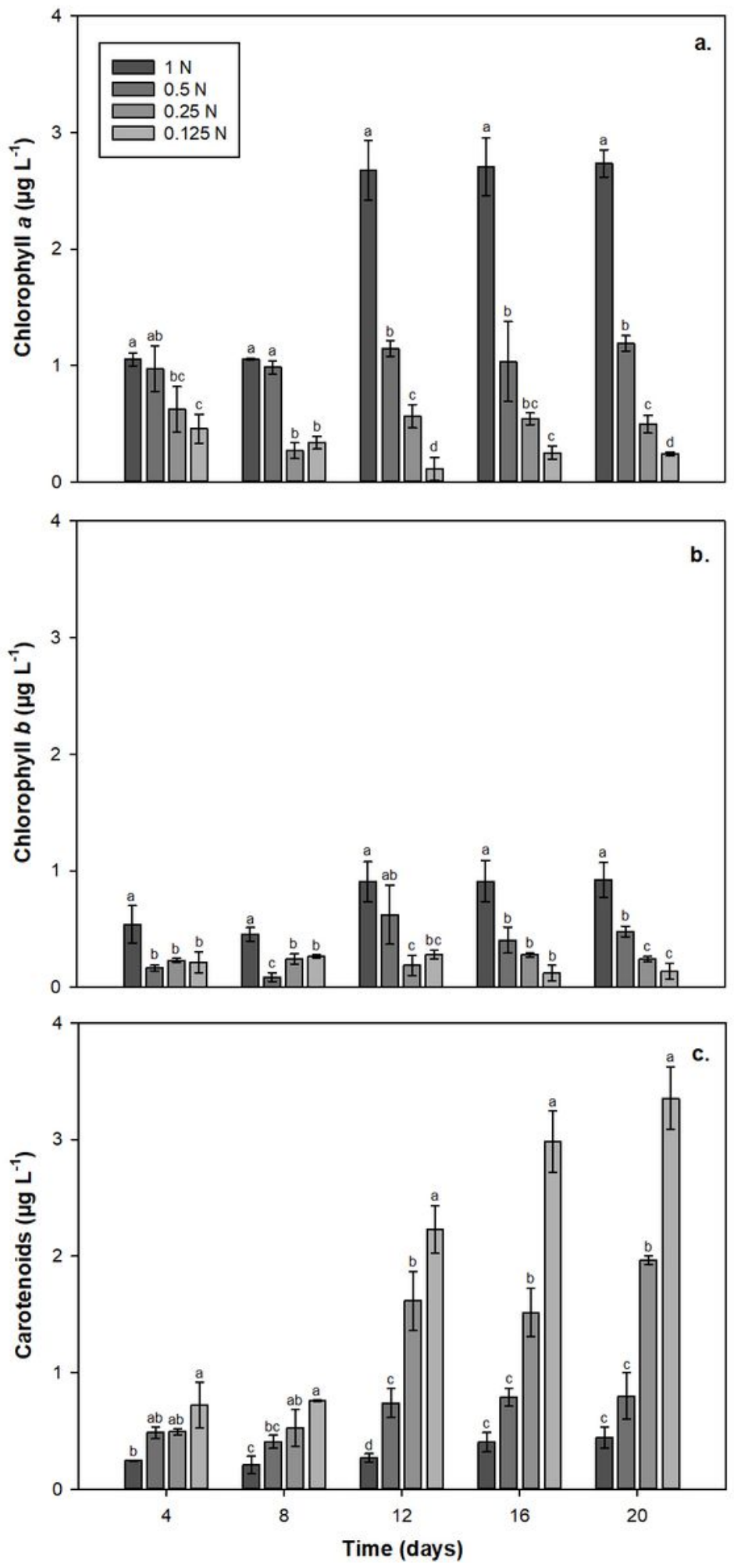

Figure 3

Effect of nitrogen limitation on the photosynthetic pigments content of P. salinarum. Data are expressed as mean $\pm S D(n=3)$. Values with the different letters represent significant difference $(p<0.05)$ between treatments. 

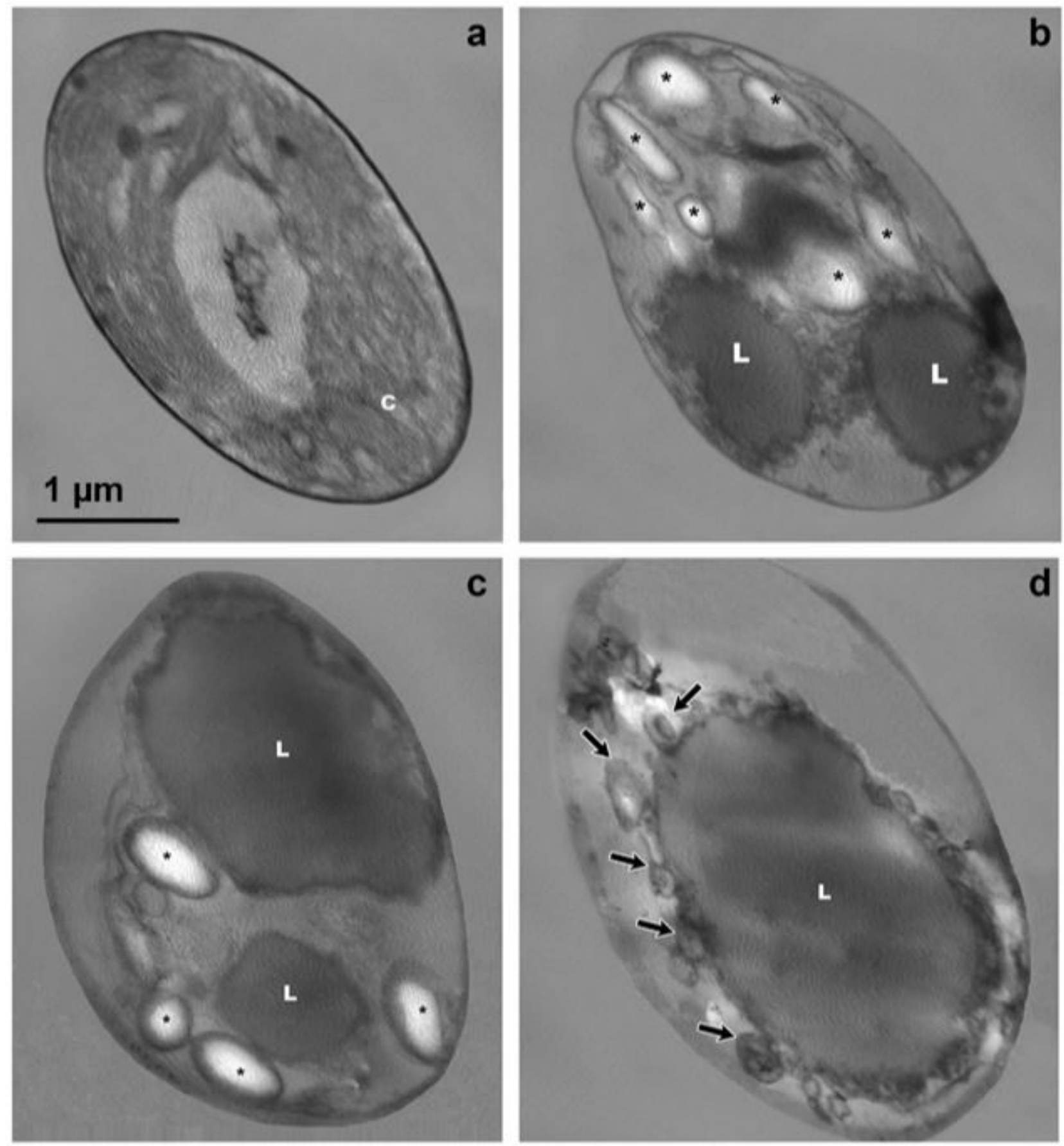

\section{Figure 4}

Cell ultrastructure of P. salinarum under nitrogen limitation. Treatments: $1 \mathrm{~N}(\mathrm{a}), 0.5 \mathrm{~N}(\mathrm{~b}), 0.25 \mathrm{~N}(\mathrm{c})$, $0.125 \mathrm{~N}$ (d). Symbols: chloroplast (c), lipid droplet (L), small lipid droplets (arrows), starch grain (*). 
Biplot (F1 and F2: $89.45 \%$ )

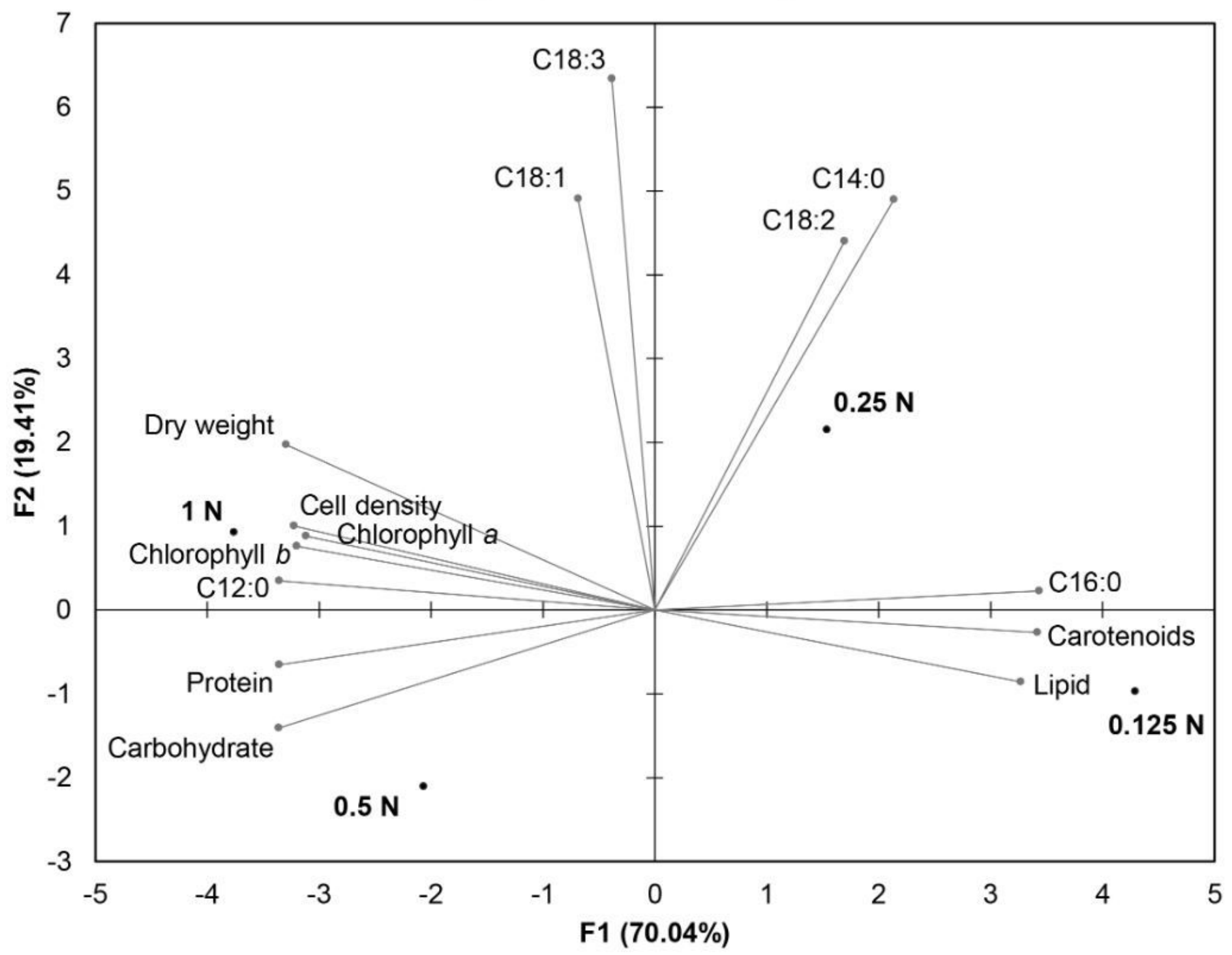

Figure 5

Principal components analysis of the growth measurements and biochemical composition of $\mathrm{P}$. salinarum under nitrogen limitation.

\section{Supplementary Files}

This is a list of supplementary files associated with this preprint. Click to download.

- Graphicalabstract.JPG 